\title{
Influence of Internal Structure and Composition on Head's Local Thermal Sensation and Temperature Distribution
}

\author{
Shuai He ${ }^{1}$, Yinghua Zhang ${ }^{1}$, Zhian Huang ${ }^{1,2, *}$, Ge Zhang ${ }^{1}$ and Yukun Gao ${ }^{1}$ (D) \\ 1 State Key Laboratory of High-Efficient Mining and Safety of Metal Mines Ministry of Education, \\ University of Science and Technology Beijing, Beijing 100083, China; He.Shuai@hotmail.com (S.H.); \\ zyhustb@163.com (Y.Z.); uh-60a@163.com (G.Z.); gaoyukunustb@126.com (Y.G.) \\ 2 Key Laboratory of Gas and Fire Control for Coal Mines (China University of Mining and Technology), \\ Ministry of Education, Xuzhou 221116, China \\ * Correspondence: huang_za@ustb.edu.cn
}

Received: 10 January 2020; Accepted: 17 February 2020; Published: 21 February 2020

\begin{abstract}
A personalized thermal environment is an effective way to ensure a good thermal sensation for individuals. Since local thermal sensation and temperature distribution are affected by individual physiological differences, it is necessary to study the effects of physiological parameters. The purpose of this study was to investigate the effects of internal structures and tissue composition on head temperature distribution and thermal sensation. A new mathematical model based on fuzzy logic control was established, the internal structure and tissue composition of the head were obtained by magnetic resonance imaging (MRI), and the local thermal sensation (LTS) index was used to evaluate the thermal sensation. Based on the mathematical model and the real physiological data, the head temperature and local sensation changes under different parameters were investigated, and the sensitivity of thermal sensation relative to the differences in tissue thickness was analyzed. The results show that skin tissue had the highest influence $\left(C_{\text {skin }}=0.0180\right)$ on head temperature, followed by muscle tissue $\left(C_{\text {muscle }}=0.0127\right)$, and the influence of adipose tissue $\left(C_{f a t}=0.0097\right)$ was the lowest. LTS was most sensitive to skin thickness variation, with an average sensitivity coefficient of 1.58 , while the muscle tissue had an average sensitivity coefficient of 0.2 , and the sensitivity coefficient of fat was relatively small, at a value of 0.04 .
\end{abstract}

Keywords: thermal sensation; biological structure and composition; tissue temperature; bioheat model; MRI analysis; sensitivity analysis

\section{Introduction}

The helmet is a basic and necessary protective piece of equipment, which is widely used in aviation, industrial, medical and military fields, etc. The variety of application, within both indoor and outdoor conditions, results in diverse thermal environments. In the design, production and use of these types of helmets, thermal comfort is one of the important factors that must be considered [1-7]. Good thermal comfort is a necessary condition for the wearer to work properly. However, due to differences in individual physiological attributes [3,5,7-9], the thermal sensation for the wearer from the equipment varies from person to person [10-15]. To ensure the thermal comfort of each individual, the thermal environment of the equipment needs to be personalized.

The thermal sensation of the human body is influenced by the external environment and individual physiological differences. In order to provide a personalized thermal environment of equipment, it is necessary to study the effects of individual physiological differences on human thermal sensation and temperature distribution. Study [16-18] shows that the thermal sensation and thermal comfort of the 
human body are strongly related to the internal heat balance, the bioheat as a by-product of metabolism is produced in living tissue at all times, and transferred to the skin from the internal organization to dissipate to the environment. In order to keep the body in a comfortable state, the relative balance of heat production and dissipation must be guaranteed [16,19-22]. A lot of studies [23-25] have been carried out on heat generation, heat dissipation and heat exchange with the environment of the body. Some scholars carried out the experiment with subjects, to study the heat generation and dissipation [26-30], and obtained the thermal response of the human body to the environment, which includes the temperature change and skin temperature distribution, as well as the subjective thermal sensation and thermal comfort state of subjects $[7,11,20,29,31-34]$. However, although these experiments can obtain the human body thermal response and the subjective thermal state of the human body, few of them can obtain the heat transfer law of internal tissues, which results in the incomplete explanation of the heat transfer process in the human body.

At the same time, mathematical models of the human body's thermoregulation were developed by researchers and used for physiological response predicting and thermal comfort assessments [9-12,14,16,35-37]. These models simplify the body into an active system and a passive system to simulate the body's thermoregulation process. The active system regulates heat production and heat loss by simulating the physiological processes of human sweating, muscle shivering, vasoconstriction and vasodilatation, and the passive system simulates the heat transfer in tissue and the heat exchange with the environment [9,16,35-39]. Based on these models, the thermal response of the human body to the environment can be calculated. Numerical methods can avoid deficiency in experimental studies, but the reliability of the results is affected by the applicability of the model, the degree of simplification of the model, and the similarity with human physiological processes and parameters.

Previous studies have paid more attention to the influence of external environmental factors on the human thermal state $[7,12,35,40,41]$. However, in fact, internal physiological difference will make the thermal state differ significantly, and hence needs to be considered in providing the personalized thermal environment or in the thermal management of personnel protective equipment [42-44], yet, it has not been deeply explored.

Therefore, the aim of this paper is to investigate the influence of the internal structure and tissue composition of the head on temperature distribution and local thermal sensation. Based on fuzzy logic control, a new mathematical model which is closer to the human thermal regulation process was established to calculate the temperature of the inner and outer layers of the head. To ensure the reliability of the results, we obtained the real internal data of the head through the MRI [45-48], and obtained the real internal head structure and tissue physiological parameters through the MRI images. Based on these real data and combined with the established mathematical model, the temperature of the inner and outer layers of the head were simulated. The local thermal sensation value was also calculated according to the local thermal sensation model. Through comparative analysis of the calculation results, the influence of internal structure and tissue composition on temperature and local thermal sensation will be clarified.

\section{Materials and Methods}

\subsection{Mathematical Model}

\subsubsection{Governing Equation and Boundary Conditions}

The bioheat was generated inside the human body and transferred to the outer layers because of the heat gradient. Pennes [41] proposed the widely used bioheat model which considers the blood perfusion effect, and the partial differential equation in a one-dimensional cylindrical coordinate system is described in Equation (1). On the left side of Equation (1) is the heat storage term. The total heat storage equals the summation of the heat conduction, heat generation, and heat exchange with blood perfusion which correspond to the three terms on the right side of the Equation (1), respectively. 


$$
\rho c \frac{\partial T}{\partial t}=k\left(\frac{\partial^{2} T}{\partial r^{2}}+\frac{\omega}{r} \frac{\partial T}{\partial r}\right)+\rho_{b l} w_{b l} c_{b l}\left(T_{b l}-T\right)+q_{m}
$$

where, $\rho$ is the specific mass $\left(\mathrm{kg} / \mathrm{m}^{3}\right), c$ is the specific heat $(\mathrm{J} / \mathrm{kg} \cdot \mathrm{K}), T$ is tissue temperature $\left({ }^{\circ} \mathrm{C}\right), t$ is the time $(\mathrm{s}), k$ is the conductivity $(\mathrm{W} / \mathrm{m} \cdot \mathrm{K}), r$ is the body element radius $(\mathrm{m}), \omega$ is a dimensionless geometry factor, $q_{m}$ is the metabolic heat production $\left(\mathrm{W} / \mathrm{m}^{3}\right), \rho_{b l}$ is the specific mass of blood $\left(\mathrm{kg} / \mathrm{m}^{3}\right), w_{b l}$ is the blood perfusion rate $\left(\mathrm{m}^{3} / \mathrm{m}^{3} \cdot \mathrm{s}\right), c_{b l}$ is the specific heat of blood $(\mathrm{J} / \mathrm{kg} \cdot \mathrm{K}), T_{b l}$ is the blood temperature $\left({ }^{\circ} \mathrm{C}\right)$. In this study, the blood perfusion term and the heat generation term were considered as constant variables according to Fiala et al. [35].

The heat transfers from the inner tissue to the skin and dissipates to environment. As the interface of heat exchange with environment, the heat flux of the skin's surface consists of convection, radiation and evaporation [16,35], as shown below:

$$
-k \frac{\partial T_{\text {skin }}}{\partial r}=Q_{c}+Q_{r}+Q_{e}
$$

The left side of Equation (2) is the heat flux on the skin's surface, the term $Q_{c}$ represents the convective heat exchange between the skin's surface and the ambient air, which consists of natural and forced convection, expressed as [35]:

$$
Q_{c}=h_{c, \text { mix }}\left(T_{s f}-T_{a i r}\right)
$$

The combined convection coefficient $h_{c, \text { mix }}$ is the function of the location of the body, the temperature difference between the surface and the air, and the effective air speed $v_{a, e f f}$ :

$$
h_{c, \text { mix }}=\sqrt{a_{\text {nat }} \sqrt{\left|T_{s f}-T_{\text {air }}\right|}+a_{f r c} v_{a, e f f}+a_{\text {mix }}}
$$

According to [35], the coefficients $a_{n a t}, a_{f r c}$, and $a_{m i x}$ have been derived from experiments and provide different values for each of the body's elements-for the head, the values are 3.0, 113, 5.7 , respectively.

The term $Q_{r}$ represents the heat exchange by radiation between head and the environment and can be expressed by [10]:

$$
Q_{r}=\sigma \varepsilon\left(T_{s f}^{4}-T_{\text {air }}^{4}\right)
$$

where, $\sigma$ is the Stefan-Bolzmann constant which is equal to $5.67 \times 10^{-8}$, and $\varepsilon$ is the emission coefficient of the skin surface, in this study, $\varepsilon=0.9$.

The term $Q_{e}$ represents the heat loss by evaporation [16]:

$$
Q_{e}=\left(3.054+16.7 h_{c, \text { mix }} W_{r s w}\right)\left(0.256 T_{s f}-3.37-P_{a}\right)
$$

where, $W_{r s w}$ is the wetness of the skin, generally, the wetness is between 0 and 1 , corresponding to the skin being totally dry and entirely wet, respectively. $P_{a}$ stands for the vapor pressure of ambient air, and can be expressed as:

$$
P_{a}=\phi_{a} P_{a}^{*}
$$

where $\phi_{a}$ is the relative humidity of the surrounding air, $P_{a}^{*}$ is the saturated vapor pressure of the surrounding air that is affected by the air temperature, the $P_{a}^{*}$ is calculated by:

$$
\lg P_{a}^{*}=7.07406-\left(1657.46 /\left(T_{a i r}+227.02\right)\right)
$$




\subsubsection{Dynamic Response of the Model}

The body temperature regulation mechanism is an important means with which to keep the body temperature relatively constant. The body regulates its temperature through vasodilation, vasoconstriction, shivering and sweating. These physiological activities are activated in response to different external environments. Generally, in a hot environment, the body will undergo vasodilation, increase sweating to increase heat dissipation, while in a cold environment, vasoconstriction and shivering will occur, increasing heat generation from reduced heat dissipation.

The dynamic response part of the model simulates the regulation of body temperature by simulating vasodilation, vasoconstriction, shivering, and sweating. Vasodilation and vasoconstriction directly affect blood flow, which corresponds to $w_{b l}$ in the governing equation. Shivering corresponds to the $q_{m}$ variable in the equation; and sweating activity affects the wetness of the skin's surface, which is the $W_{r s w}$ variable in boundary conditions.

The simulation of thermoregulation is based on the definition of the body's thermal signals. The signals were calculated by the temperature difference between each layer and its set point, which is Error $=T-T_{\text {set }}$. If the Error $>0$, then the $S_{i g} g_{w a r m}=E r r o r$ and the $S i g_{\text {cold }}=0$, in this situation vasoconstriction and sweating occur. If the Error $<0$, then the Sigcold $=$ Error and the $S i g_{w a r m}=0$, and the vasodilation and shivering occur. Here, $S_{i g}$ warm $_{\text {and }}$ ang ${ }_{\text {cold }}$ are the warm and cold signals, respectively.

Based on the above, a dynamic temperature regulation model based on fuzzy control is established. The fuzzy control model includes one input variable and three output variables. The input variable is the cold and warm sensation signal of the human body, and its calculation process is described above. The output variables are the blood flow control coefficient, metabolic heat production control coefficient and skin humidity control coefficient. The basic structure of the control model is shown in Figure 1a.

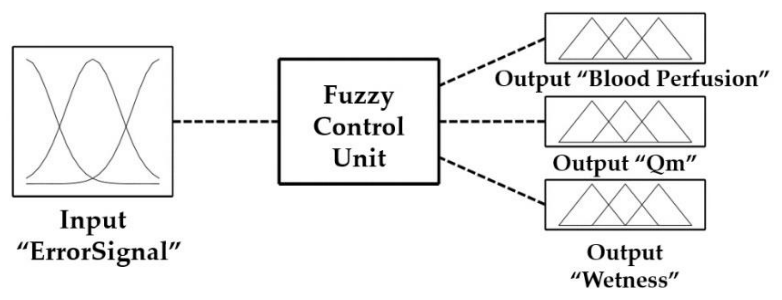

(a)
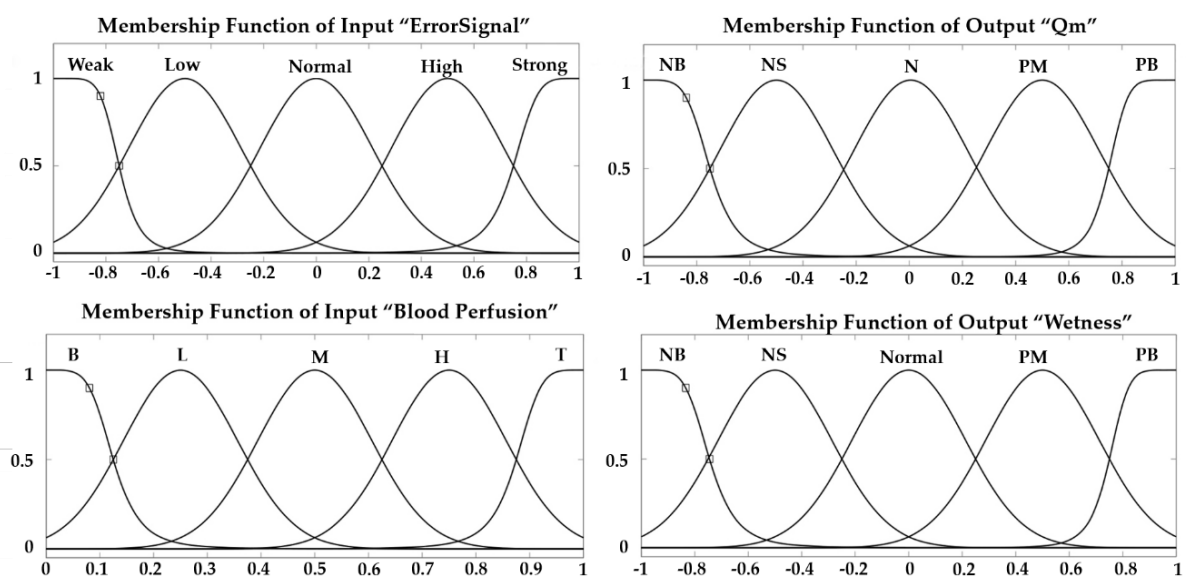

(b)

Figure 1. (a) The structure of fuzzy control model; (b) membership functions of fuzzy control model. 
According to the regulation rules of the human body, the corresponding fuzzy control rules are established. If the input parameter is negative, the body metabolism heat production will increase, and the blood perfusion rate of the skin layer will be decrease. If the input parameters are positive, the blood perfusion rate of the skin layer and the skin wetness will increase. The membership function image of the input and output variables is shown in Figure $1 \mathrm{~b}$.

\subsubsection{Thermal Sensation Index}

Thermal sensation is the body's subjective description of its surrounding environment which is highly correlated with the skin and internal tissue temperatures. Although it is difficult to obtain an exact definition of thermal comfort conditions, it is possible to evaluate the body's thermal sensation and comfort by body temperatures. Zhang $[49,50]$ proposed the local sensation index model and local comfort model for each part of the human body-which is known as the UC Berkeley thermal comfort model (UCB model) or Zhang's model - to evaluate the environment, with the aim of predicting "satisfaction" or "dissatisfaction" with the thermal environment. In Zhang's model, the thermal sensation index is defined in a range from -4 to 4 . The negative values of the local thermal sensation (LTS) index represent the "cold" sensation while the positive values represent the "hot" sensation. It is an extended ASHRAE 7-point scale, adding "very hot" and "very cold" to accommodate extreme environments: 4, "very hot"; 3 , "hot"; 2 , "warm"; 1 , "slightly warm"; 0 , "neutral"; -1, "slightly cool"; -2 , "cool"; -3 , "cold"; -4 , "very cold" [49]. In this paper, the thermal state of the head is evaluated according to Zhang's thermal sensation model in which the LTS index is expressed as follows:

$$
\text { LTS }=4 *\left(\frac{2}{1+\operatorname{EXP}\left(-C_{1} * \Delta T_{s k, l o c}-K_{1} *\left(\Delta T_{s k, l o c}-\Delta T_{s k, m}\right)\right)}-1\right)+C_{2} \frac{d T_{s k, l o c}}{d t}+C_{3} \frac{d T_{\text {core }}}{d t}
$$

where LTS is the local thermal sensation; $C_{1}$ is a coefficient that varies for different body parts, (for the head $C_{1}=0.38$ when the $\Delta T_{s k, l o c}$ is negative and $C_{1}=1.32$ when the $\Delta T_{s k, l o c}$ is equal or greater than zero); $\Delta T_{s k, l o c}$ is the difference between the local skin temperature and its set-point temperature $\left({ }^{\circ} \mathrm{C}\right)$; $K_{1}$ is a coefficient with a value from 0 to 1 that varies for different body parts( for the head, $K_{1}=0.18$ ); $\Delta T_{s k, m}$ is the difference between mean skin temperature $\left({ }^{\circ} \mathrm{C}\right)$ and the mean set-point temperature $\left({ }^{\circ} \mathrm{C}\right)$; $C_{2}$ and $C_{3}$ are the thermal capacities at the skin and core nodes respectively [11].

\subsection{MRI Analysis of Head Composition and Structure}

One of the factors that affect the numerical results is the inappropriate simplification of human body segments. In the study of Yutaka Kobayashi et al. [9], the head segment was simplified into a shape with four layers: the core layer, the first layer, the second layer and the skin layer. Shinichi Tanabe et al. [51] also divided the human body into 16 segments, of which the head segment was simplified as a four layer shape consisting of core, muscle, fat and skin layers. In the circumstances of whole-body thermal response studies, a reasonable simplification is acceptable because the thermal response details within a particular body part is not of important. However, this does not mean that the differences can be neglected. In this study, the micro differences of the thermal state of the head which are affected by internal tissue differences are of interests. Hence, the head cannot be treated as having a simple geometry; the internal structure and the tissue differences need to be considered.

To obtain the detailed parameters of the structure and tissue of the head, the MRI method was used. Muscle and adipose composition within the extracranial part of head have different signals on the image, hence, the proper threshold levels were chosen to sub-select different tissues, and then the threshold values were manually adjusted for excluding other tissues. The internal structure of the head at multiple views and levels are shown in Figure 2a, and the results of the selection of different tissues are shown in Figure 2b. Figure 2c is the comparison of tissue thickness between different individuals at the same section of the head. 


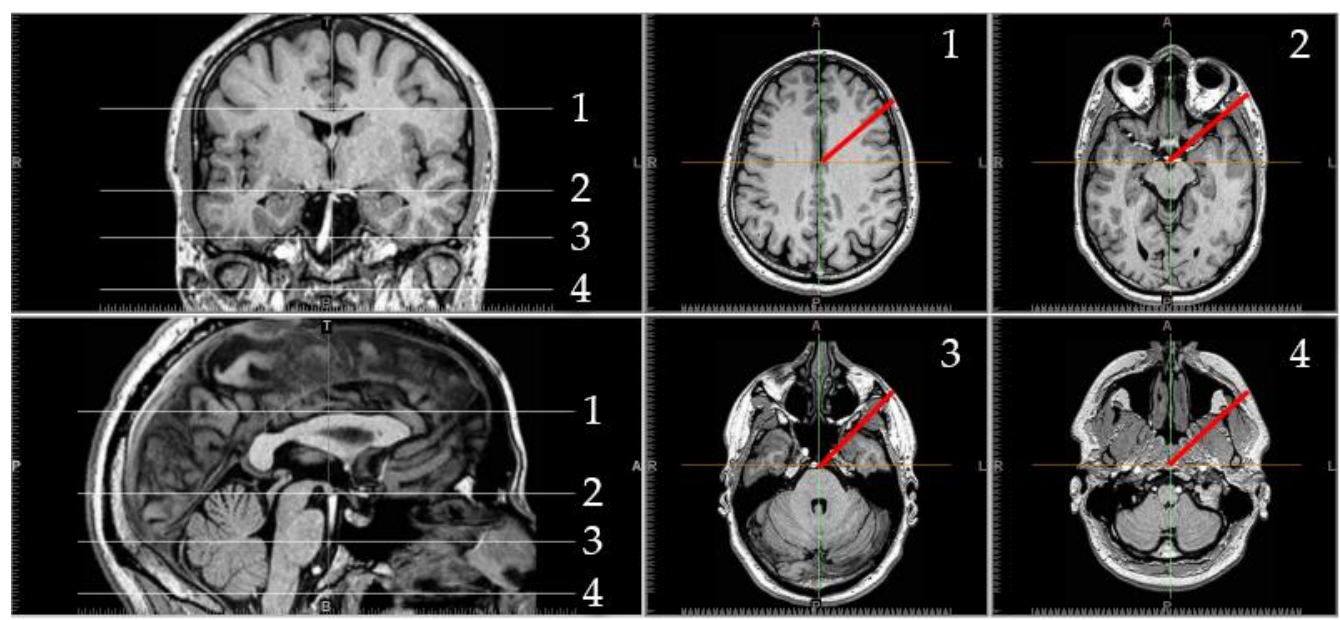

(a)

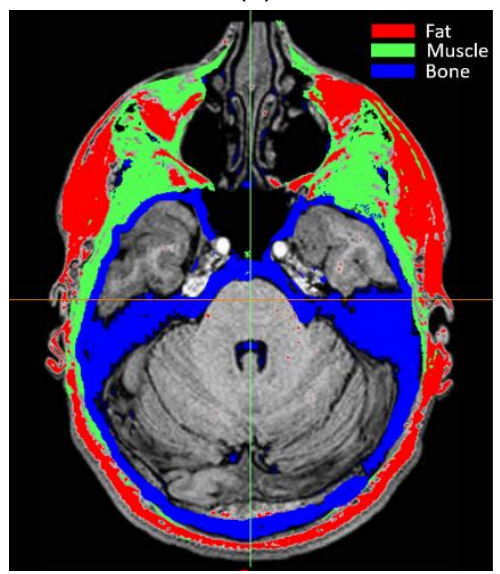

(b)

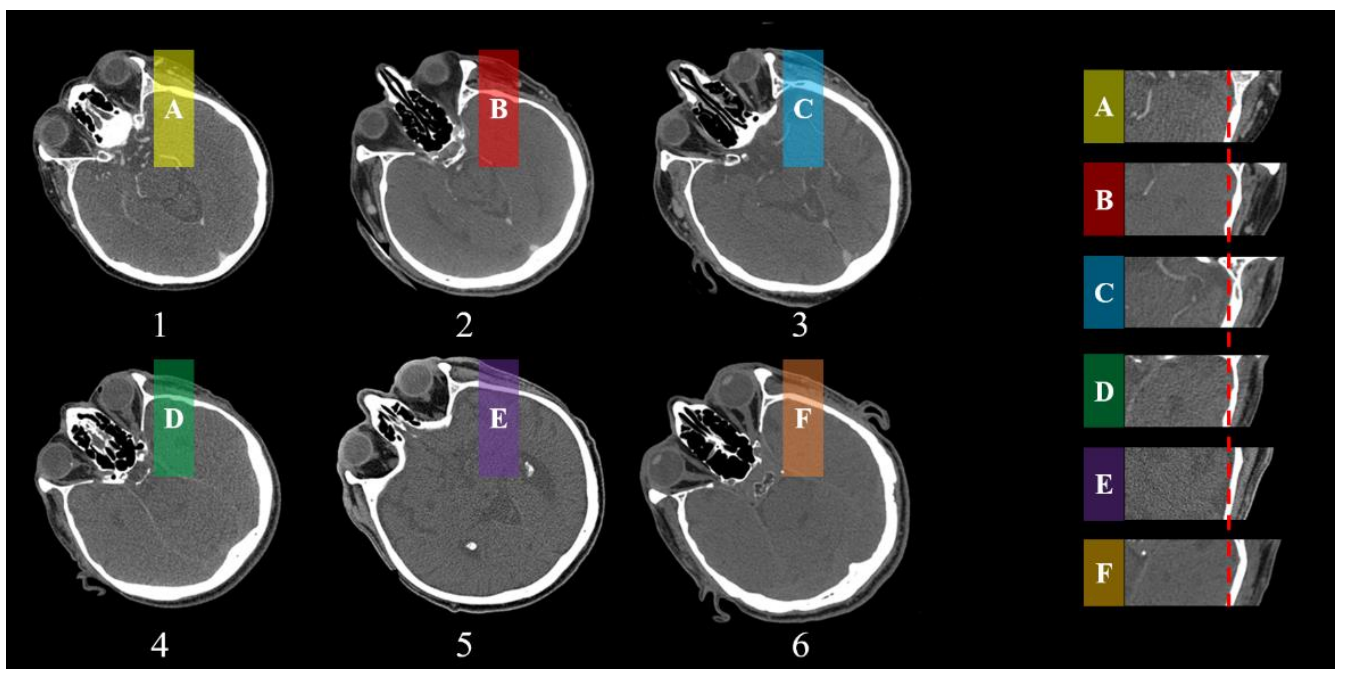

(c)

Figure 2. The structures of different sections of the head obtained by MRI. In (a), the two left images are the front and side view of the head. Sub images of 1,2,3, and 4 on the right side show the different sections from the top to bottom of the head. The image (b) shows the mask results of different tissues of section (3). The image (c) shows the comparison of tissue thickness between different individuals at the same section of the head. 
As shown in the Figure 2, the head is not a symmetrical entity. The internal structure of the head is complex and the tissue components are diverse. The radial tissue is unevenly distributed on different levels. In general, the head is composed of a skull part and a face part, the skull part is mainly composed of brain tissue, skull, muscle tissue, adipose tissue, and skin from the inside to the outside, and the composition of the face is more complicated. A large amount of muscle tissue is attached to these bones, and adipose tissue and skin layers are located outside the muscle tissue. From the MRI image, it can be found that in different layers, the distribution of muscle tissue, adipose tissue and skin layer is uneven, and the thickness is significantly different. In the skull and facial parts, the radial distribution of the tissues and structures are significantly different. The cavity of the airway is located near the bottom of the skull, and the internal structure of the bilateral sides is complicated. Muscle tissue and skeletal tissue exist alternately in this part.

The physical and thermal properties of tissues are determined according to [35] and listed in Table 1. The measured results of the structure and tissue distribution along the red markers in Figure $2 \mathrm{a}$ are for the four sections are shown in Table 2.

Table 1. Physical and thermal properties of different tissue [35].

\begin{tabular}{cccccc}
\hline \multirow{2}{*}{ Tissue } & $k$ & $\rho$ & $c$ & $w_{b l}$ & $q_{m}$ \\
\cline { 2 - 6 } & $\mathbf{W} / \mathbf{m} \cdot \mathbf{K}$ & $\mathbf{k g} / \mathbf{m}^{3}$ & $\mathbf{J} / \mathbf{k g} \cdot \mathbf{K}$ & $\mathbf{m}^{3} / \mathbf{m}^{3} \cdot \mathbf{s}$ & $\mathbf{k g} / \mathbf{m}^{\mathbf{3}}$ \\
\hline Brain & 0.49 & 1080 & 3850 & 10.132 & 13,400 \\
Bone & 1.16 & 1500 & 1591 & 0 & 0 \\
Muscle & 0.42 & 1085 & 3768 & 0.538 & 684 \\
Fat & 0.16 & 850 & 2300 & 0.0036 & 58 \\
Skin & 0.47 & 1085 & 3680 & 5.48 & 368 \\
\hline
\end{tabular}

Table 2. Structure and tissue thickness of different sections along the red markers in Figure 2a.

\begin{tabular}{cccccccc}
\hline \multicolumn{2}{c}{$\mathbf{1}$} & \multicolumn{2}{c}{$\mathbf{2}$} & \multicolumn{2}{c}{$\mathbf{3}$} & $\mathbf{4}$ \\
\hline Tissue & $\begin{array}{c}\text { Thickness } \\
\mathbf{( c m )}\end{array}$ & Tissue & $\begin{array}{c}\text { Thickness } \\
\mathbf{( c m )}\end{array}$ & Tissue & $\begin{array}{c}\text { Thickness } \\
\mathbf{( c m )}\end{array}$ & $\begin{array}{c}\text { Tissue } \\
\text { Thickness } \\
\mathbf{( c m )}\end{array}$ \\
\hline Brain & 8.81 & Brain & 7.37 & Brain & 1.37 & Muscle & 3.18 \\
Bone & 0.46 & Bone & 0.57 & Bone & 1.46 & Bone & 0.48 \\
Muscle & 0.31 & Muscle & 1.71 & Brain & 4.5 & Muscle & 3.56 \\
Fat & 0.78 & Fat & 0.75 & Bone & 0.66 & Bone & 0.58 \\
Skin & 0.27 & Skin & 0.31 & Muscle & 0.69 & Muscle & 0.46 \\
- & - & - & - & Fat & 0.76 & Fat & 0.52 \\
- & - & - & - & Skin & 0.36 & Skin & 0.4 \\
\hline
\end{tabular}

\subsection{Methodology Framework}

In the current work, the purpose was to investigate the influence of the difference of the internal structure of the human head and the biological tissue composition on tissue temperature and local thermal sensation through a numerical method. Firstly, a mathematical model of biological heat transfer was established, which included control equation, boundary condition, and dynamic response. By solving the mathematical model, the temperature distribution of the head tissue can be obtained. The boundary condition describes the heat exchange between the human body and the environment. The dynamic response part regulates the heat exchange by adjusting the physiological parameters in boundary conditions and in the governing equation. The internal structure of the head and the physical parameters of the tissue were obtained by MRI. By inputting these different physiological parameters into the model, we were able to obtain the tissue temperature distribution and local thermal sensation value under the corresponding conditions, and then analyze the influence of input parameters on the output. The framework is shown in Figure 3. 


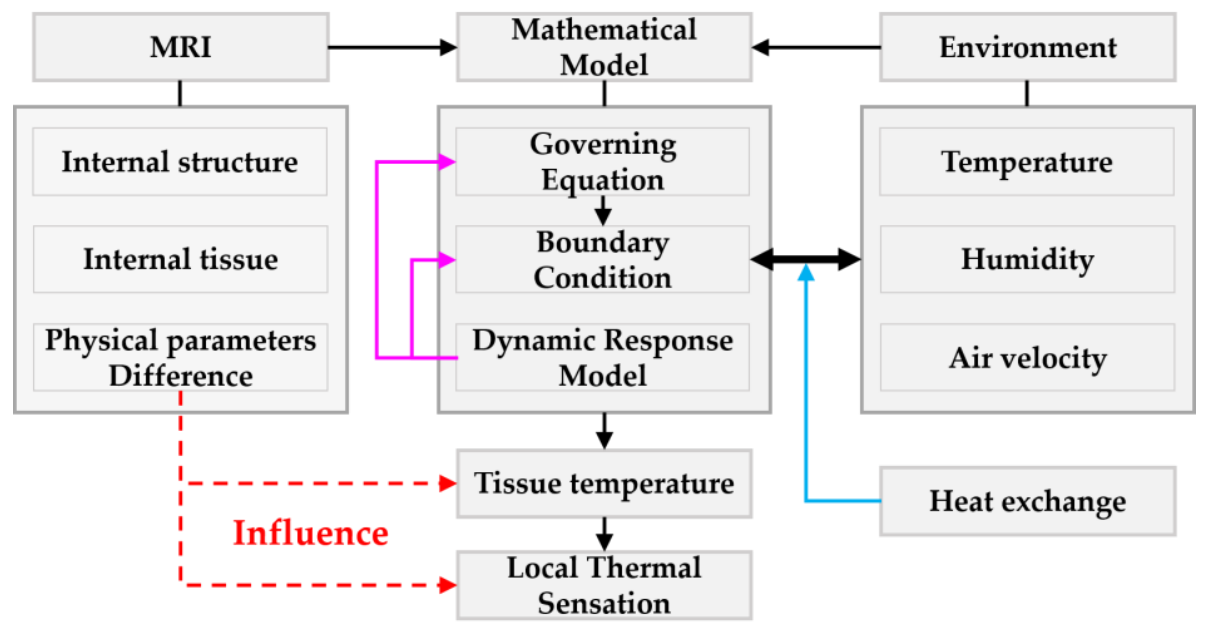

Figure 3. The methodology framework of the study

\section{Results and Discussion}

\subsection{Model Validation}

To validate the mathematical model of Section 2.1, two different cases are considered and the results are compared with published experimental and numerical data.

The first case is the comparison to the results reported in [16]. Experimental data are of the core temperatures and skin temperatures of human subjects exposed to the ambient conditions of $28.5^{\circ} \mathrm{C}$, and $31 \%$ relative humidity $(\mathrm{RH})$, at a steady state for $4 \mathrm{~h}$. The results are shown in the Figure 4 , and it can be seen that the results of the model used in this article are generally consistent with the published data. The reason for the slight difference is that the model uses the actual parameters of the human body's structure and the differences in boundary conditions. However, from the overall trend, the calculation results are acceptable.
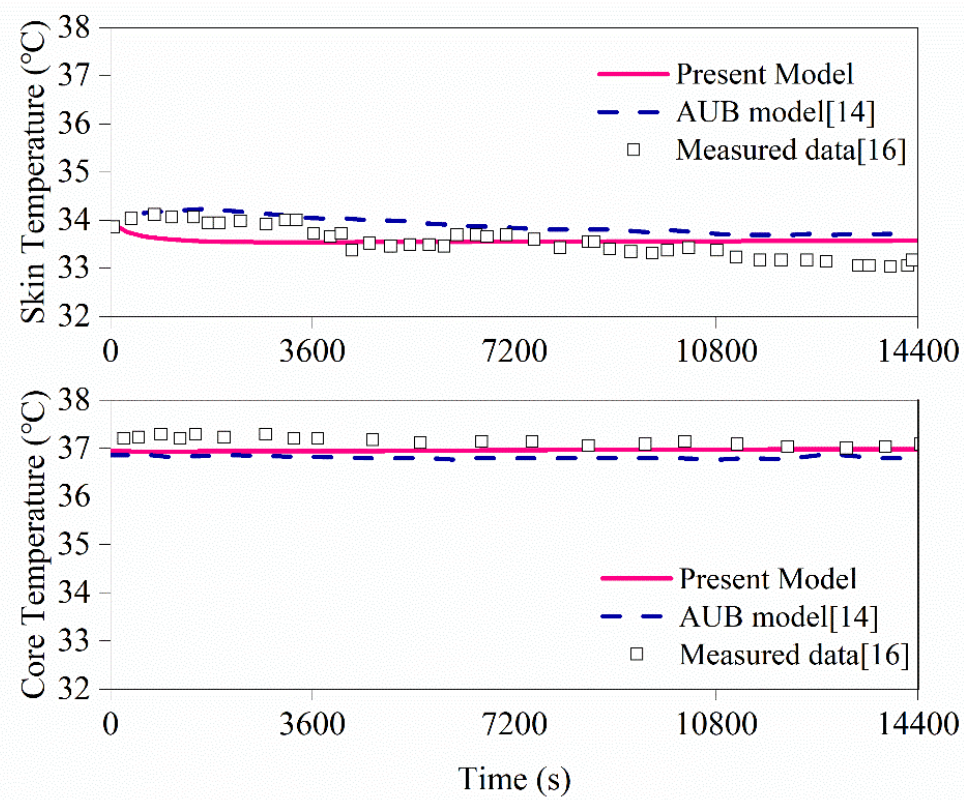

Figure 4. Comparison of simulated results of the model used in this study with the published experimental data [16], and simulated results of American University of Beirut model (AUB model) [14] for skin temperature and core temperature at constant ambient conditions of $28.5^{\circ} \mathrm{C} / 31 \% \mathrm{RH}$. 
In the second case, the ambient temperature and relative humidity change from $30{ }^{\circ} \mathrm{C} / 40 \%$ to $48{ }^{\circ} \mathrm{C} / 30 \%$ for the first two hours, and then change back to $30{ }^{\circ} \mathrm{C} / 40 \%$ in the last hour. Figure 5 shows the simulation results of the model in this paper and the measured data of [16]. It can be found that the temperature of both the skin and the inner tissue are affected by the ambient environment, the increase of air temperature results in the increase of skin temperature. The simulated results of the mathematical model are in agreement with the measured results.

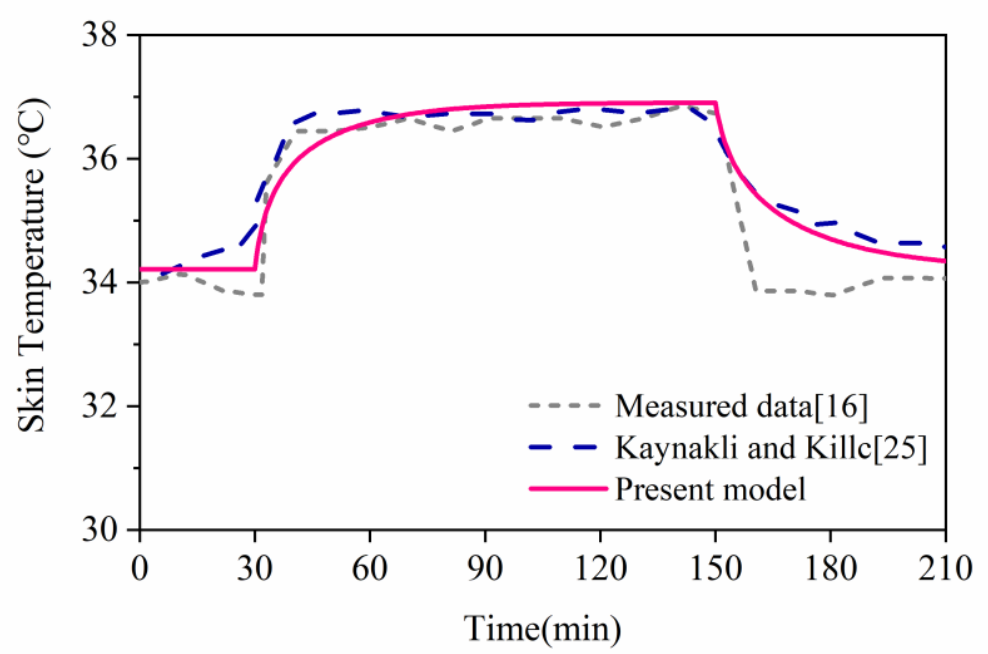

Figure 5. Comparison of the simulated results with the measured data [16], and Kaynakli and Kilic [25] as the ambient temperature step change.

One of the most commonly used methods to assess the accuracy of data is the root means square error (RMSE). It describes the degree of coincidence among measured and simulated data.

If we assume that we have a set of measured data $M$ and the simulated result $S$, then the definitions for the RMSE is

$$
R M S E=\sqrt{\frac{1}{N} \sum_{i=1}^{N}\left(S_{i}-M_{i}\right)^{2}}
$$

where $M_{i}$ is the measured data; $S_{i}$ is the simulated data; $\mathrm{n}$ is number of data pairs.

In general, if the computed values of RMSE are small, the simulated data and the measured data agree well.

According to Equation (10), the RMSE of the present model and other models in the above two cases are calculated. The results are shown in Table 3 below.

Table 3. Root mean square error results of different models.

\begin{tabular}{cccc}
\hline & & \multicolumn{2}{c}{ RMSE } \\
\hline \multirow{4}{*}{ Case1 } & Core & Present Model & AUB model \\
& Skin & 0.2127 & 0.3517 \\
& & 0.3080 & 0.3415 \\
Case2 & Skin & Present Model & RMSE \\
\hline
\end{tabular}

From the results of RMSE in the table, it can be seen that the RMSE value of the present model is smaller than that of the corresponding model, indicating that the gap between the results of the present model and the measured values is smaller, and the prediction accuracy of the existing model is improved compared with that of the other models. 


\subsection{Influence of Different Structures on Tissue's Temperature Distribution}

The different distribution of head skin temperature has been observed in many studies, the temperature of the forehead, cheek, mouth and nose is not uniform. The skin temperature of the head and face is not only different with the change of the environment, but the stable skin temperature is also different under the same external environment. The difference in the internal structure of the head is the main cause of this result. Based on the MRI analysis and measurement results, the radial temperature distributions of the four sections in Figure 2a were calculated. The exposure time was $2 \mathrm{~h}$, the ambient environment temperature and relative humidity ( $\mathrm{RH}$ ) were $28{ }^{\circ} \mathrm{C} / 30 \%$, and the air velocity was $0.05 \mathrm{~m} / \mathrm{s}$. The temperature results of the skin and inner tissues were obtained and are shown in Figure 6.
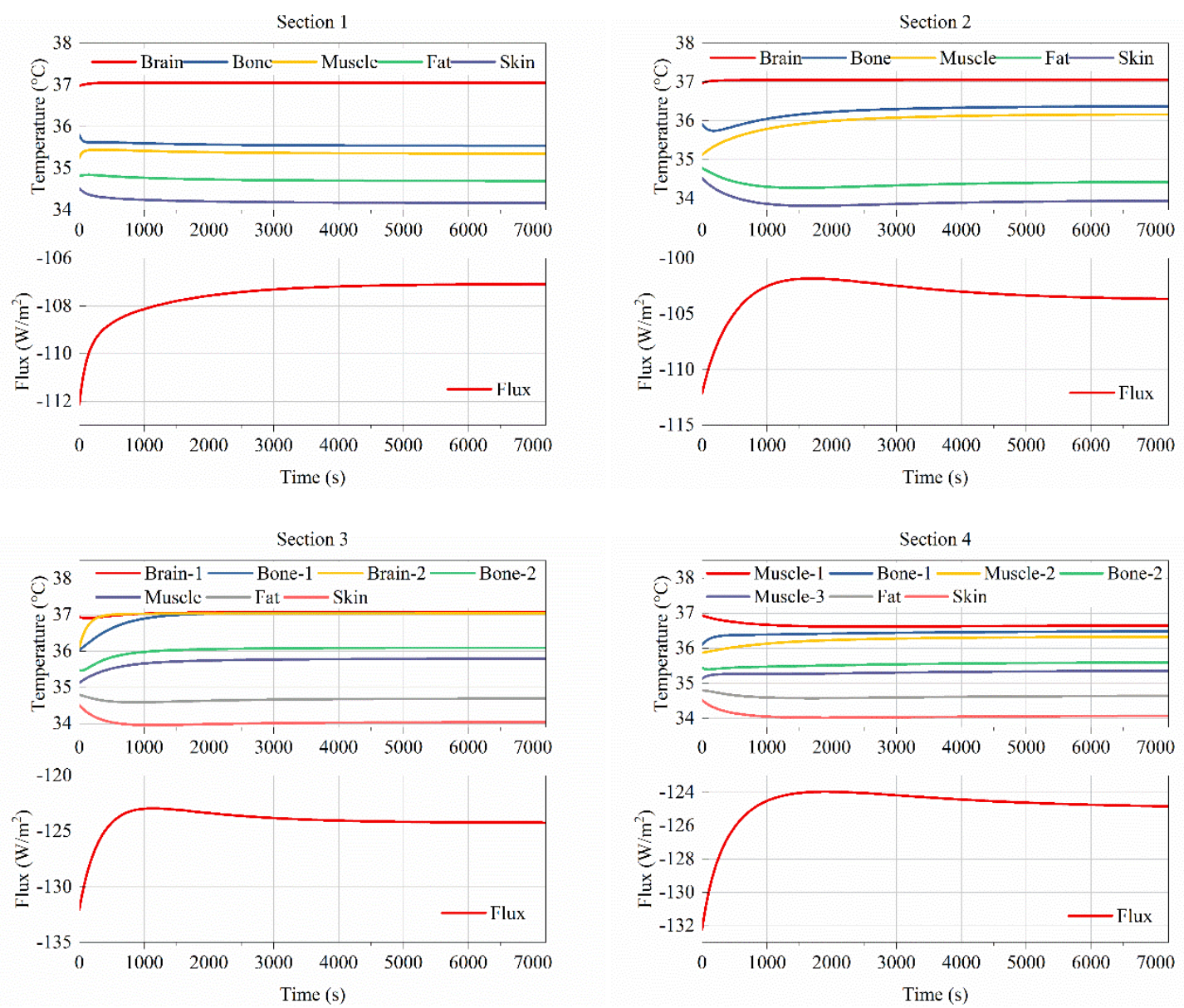

Figure 6. Comparison of the temperatures influenced by different compositions and structures of different layers of the head.

From the results in Figure 6, it can be found that there are obvious differences in the temperature distribution in different sections. The four layers in Figure $2 \mathrm{a}$ are structures that can roughly represent the forehead, the part around the eyes, the part of the cheeks, and the mouth and nose.

For Sections 1 and 2, although the internal structural composition is similar, the temperature of the core and the skin temperature are different due to the different thickness of the tissues. The skin temperature of Section 2 is significantly lower than that of Section 1. In Section 2, the temperature of the bones and muscles is significantly higher than the corresponding temperature in Section 1 . The reason is that the thickness of the muscle tissue in Section 2 is greater than that in Section 1. For Sections 3 and 4, the structure and tissue distribution are both different, resulting in different internal core temperatures and internal tissue temperatures. The core temperature of Section 3 is slightly lower than 
that of Section 4 , but the most stable temperature is almost the same, while the skin temperature of Section 3 is slightly lower than that of Section 4.

From the final stable skin heat flux, the four sections are also quite different. This explains why the head and face have different temperature distributions, internal structure differences, and different tissue thicknesses, leading to differences in internal heat transfer and skin heat loss, which are reflected in uneven skin temperature distribution.

\subsection{Effect of Tissue Thickness Step Change on Temperature Distribution}

It is reported that the percentage of fat in each part of the body will affect the temperature distribution [43]. A higher proportion of fat leads to a lower skin temperature, while the temperature of the tissue inside the fat layer is higher, which indicates that the fat plays a role in heat insulation.

For different individuals, in addition to the difference in fat content, muscle tissue and skin also have different thicknesses and distributions. Although the structure of the same part does not differ much, the thickness of muscle tissue, adipose tissue, and skin varies from person to person. Even in the same person, the parameters of these tissues can change under different physiological conditions. In order to study the effect of these three tissues on head temperature distribution, we assume that the thickness of muscle tissue, adipose tissue, and skin varies from 0.1 to $1.5 \mathrm{~cm}, 0.1$ to $1.5 \mathrm{~cm}$ and 0.05 to $0.5 \mathrm{~cm}$, respectively. The air temperature, relative humidity and wind speed of the ambient environment are $28{ }^{\circ} \mathrm{C}, 30 \%$ and $0.05 \mathrm{~m} / \mathrm{s}$, respectively. Based on the physiological structure of the forehead, calculations were performed to obtain the effect of different tissue thicknesses on the tissue temperature of each layer. The calculation results are shown in Figures 7-9.

Figure 7 shows the results of the effects of changes in muscle tissue thickness on the temperature of each layer, and Figures 6 and 9 show the results of changes in fat thickness and skin thickness on the temperature of each layer.

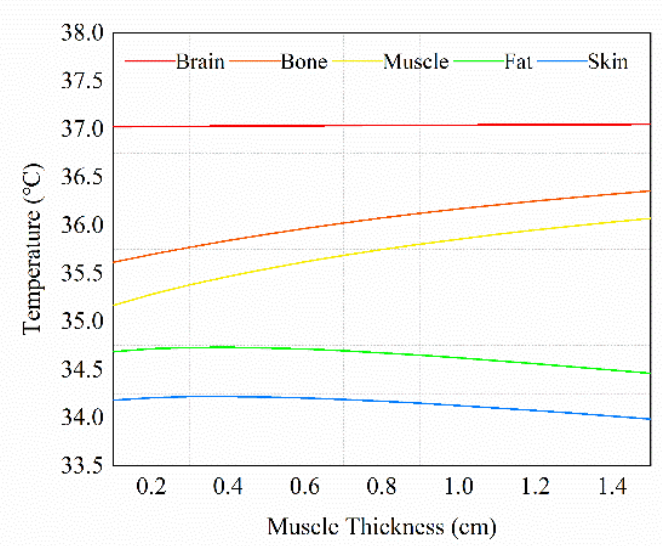

(a)

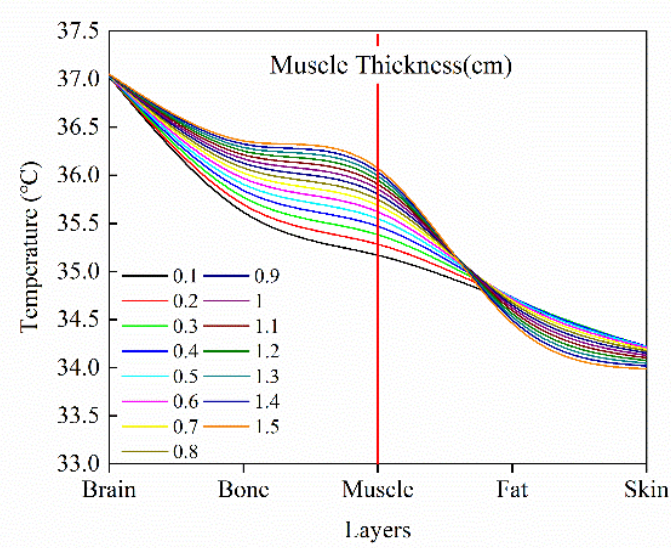

(b)

Figure 7. (a) Temperature variation by muscle thickness step change; (b) Tissues temperature distribution under different muscle thickness.

As shown in Figure 7a, skin temperature continues to decrease as muscle thickness increases, and the temperature of the fat layer has the same trend as the skin layer. While, on the contrary, the temperature of brain, bone and muscle layers are increased, of which the bone and muscle layers increased more obviously, and the temperature of the brain layer stayed relatively stable. The trends are clearly shown in Figure $7 \mathrm{~b}$, showing that not only the inner tissues are affected, but also the muscle layer itself is affected by the increase of its thickness. 


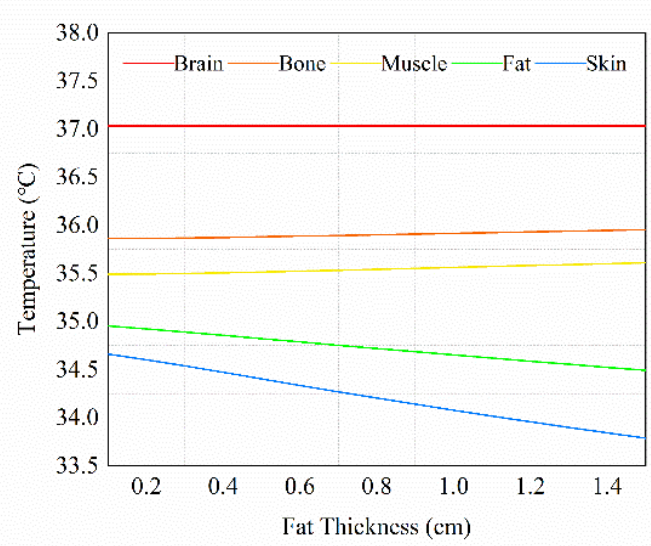

(a)

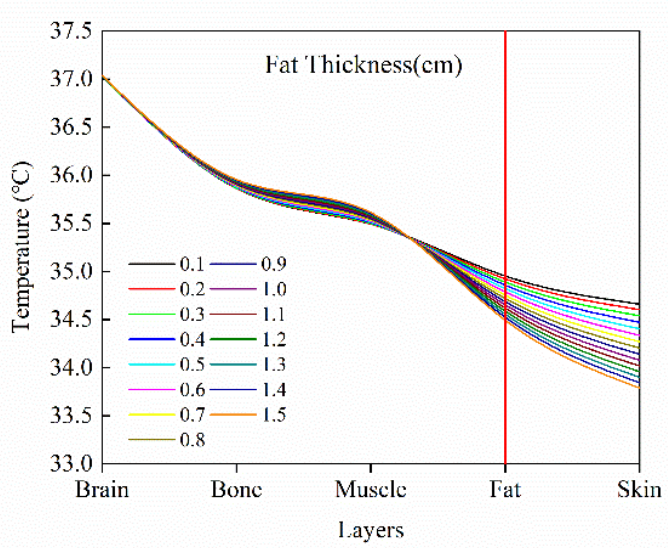

(b)

Figure 8. (a) Temperature variation by fat thickness step change; (b) Tissues temperature distribution under different fat thickness.

Figure 8 a shows the tissue temperature change with the changes of fat thickness. The temperatures of the brain, bone and muscle are increased, and the fat and skin layers' temperatures decreased as the fat thickness increased. The general trend of the five layers are similar to that in the case of muscle thickness step change, but the absent value of temperature change is different. Temperature changes caused by changes in fat thickness are not as obvious as temperature differences caused by changes in muscle tissue thickness. The temperature changes of muscles and bones are very slow, rising only in a small range, while the temperature of brain tissues is not obvious, and basically remains stable. The temperature of the adipose tissue and the skin drops significantly; a trend of temperature change that is different from that in the case of muscle thickness changes. The increase in fat thickness does not cause the temperature of the fat layer to rise, but rather causes it to decrease, indicating that fat does play a role in blocking heat. This phenomenon is consistent with experimental observations in [42,43].

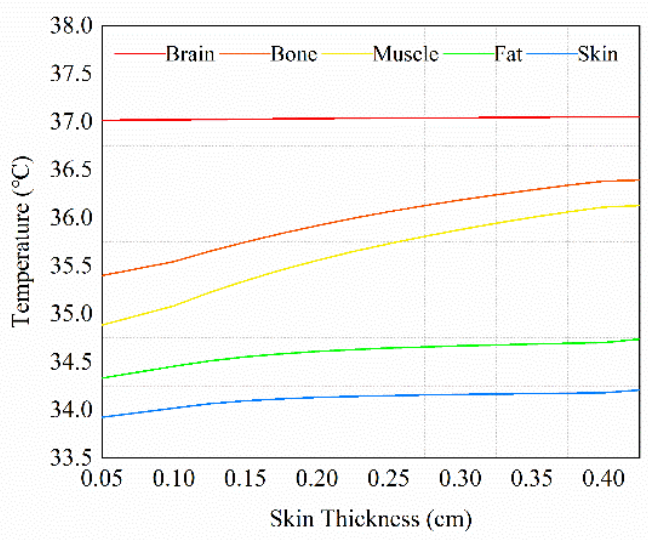

(a)

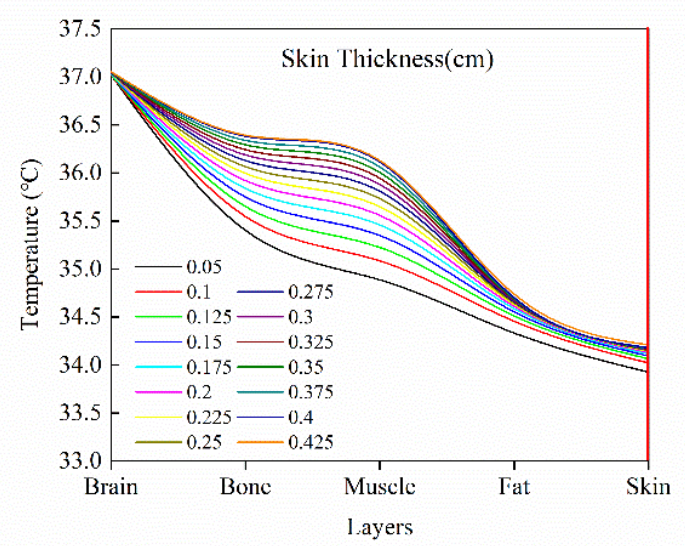

(b)

Figure 9. (a) Temperature variation by skin thickness step change; (b) Tissues temperature distribution under different skin thickness.

The skin layer is the outer layer of the body, and the barrier to protect human body, and is also the interface to exchange heat, water and gas with the environment. Although the skin is a thin layer, its function of heat exchange is significant. The results in Figure 9 show that the change in the thickness of the skin layer also has a certain effect on the temperature distribution. As the thickness of the skin increases, the tissue temperature inside the skin layer tends to rise. The temperature of brain 
tissue is similar to the previous situation, although there is a small change, it remains stable. Similar to the change in muscle thickness, the temperature of bones and muscles showed an upward trend, and reached a higher position. The temperature of the fat layer also increased with the same trend as the skin layer.

From the results of the above three examples, it can be seen that changes in the thickness of muscle tissue, adipose tissue, and skin can all affect the distribution of head temperature. In order to compare the effects of the three tissues on temperature changes, the temperature data of the three examples were normalized and then a regression analysis was performed. The regression data are shown in Table 4.

Table 4. Regression results of normalized temperature and tissue thickness change in Figures 7-9.

\begin{tabular}{ccccccccccc}
\hline \multirow{2}{*}{ Curve } & \multicolumn{3}{c}{ Muscle (Figure 7) } & \multicolumn{3}{c}{ Fat (Figure 8) } & \multicolumn{3}{c}{ Skin (Figure 9) } \\
\cline { 2 - 10 } & Intercept & Slope & r & Intercept & Slope & r & Intercept & Slope & r \\
\hline Brain & 0.9993 & 0.00074 & 0.99104 & 0.9999 & 0.00009 & 0.9962 & 0.999 & 0.0011 & 0.9885 \\
Bone & 0.9798 & 0.02151 & 0.99104 & 0.9971 & 0.0029 & 0.9962 & 0.9709 & 0.0318 & 0.9885 \\
Muscle & 0.9758 & 0.02597 & 0.98721 & 0.9961 & 0.0038 & 0.9962 & 0.9639 & 0.0394 & 0.9862 \\
Fat & 1.0016 & -0.0081 & -0.91704 & 1.001 & -0.0143 & -0.9999 & 0.99 & 0.0107 & 0.9288 \\
Skin & 1.0014 & -0.0071 & -0.91478 & 1.0017 & -0.0274 & -0.9995 & 0.9934 & 0.0071 & 0.8969 \\
\hline
\end{tabular}

From the results of the regression analysis, the three tissue thickness changes generally show a linear relationship with the temperature changes, and a high linear fitting degree indicates that there is a strong correlation between temperature changes and tissue thickness changes.

Here we define a coefficient to evaluate the effect of tissue thickness changes on head temperature.

$$
C=\frac{1}{n} \sum_{i=1}^{n}\left|S_{i}\right|
$$

where, $C$ is the influence coefficient, $S_{i}$ is the slope of each tissue layer in the regression analysis, $n$ is the total number of tissue layers.

Then, the influence coefficients of muscle, fat and skin are: $C_{\text {muscle }}=0.0127, C_{f a t}=0.0097$ and $C_{\text {skin }}=0.0180$, respectively.

At present, research on the influence of body composition on temperature distribution is mainly focused on the effect of the proportion of adipose tissue on temperature. The results of these studies show that the thickness of the fat layer and the temperature of the skin have a negative correlation. This phenomenon has been verified in the calculation results of this paper. Moreover, the influence of different combinations of tissue or biological structures on temperature distribution is also observed in the study. Meanwhile, other tissues of the body also affect the temperature distribution. As mentioned in reference [42,43], the percentage change of muscle tissue will affect the average temperature of the skin, which is also reflected in the calculation results.

The fat layer inside the body parts serves as a heat insulator with a low thermal conductivity of $k$ $=0.16$. As the thickness of fat increased, the total heat resistance rises, and it becomes more difficult for inner heat to transfer to outer layers, which results in skin temperature drop, meanwhile the heat accumulates in the inner tissues and results in a temperature increase.

The muscle and the skin layers have a similar effect as the fat layer; a thickness increase of muscle and skin leads to the temperature rise of inner tissue layers and temperature drop of outer layers. However, the difference lies in the effect on the layer itself. The thickness increase in the fat layer does not result in a temperature increase of the fat layer itself, but in the case of thickness change of muscle and skin layers, an increase of thickness in the two layers results in the temperature rise of the muscle layer and the skin layer. The reason for this result is that the fat tissue has a low thermal conductivity $(k=0.16)$, when the thickness of the fat layer increases, the amount of heat transferred to the adipose tissue decreases, and because of its lower metabolic heat production rate $\left(q_{m}=58\right)$ and lower blood 
perfusion rate $\left(w_{b l}=0.0036\right)$, the overall caloric accumulation of itself decreases, leading to a decrease in the temperature of the fat layer itself, and consequent drop in skin temperature.

On the other hand, the thermophysical parameters of muscle tissue and skin tissue are very close, which leads to very similar laws of temperature changes of muscle tissue and other tissues caused by changes in skin thickness. The temperature of the internal tissue increases, while the temperature of the external tissue decreases. The only difference is that the muscle tissue and skin are in different positions in the physiological structure. The skin is located on the outermost side of the physiological structure. As a result, changes in skin thickness cause the temperature of all internal tissues to rise, including the temperature of the skin layer. The skin layer is located in the outermost layer, so it has a blocking effect on the heat in all the inner layers.

\subsection{Thermal Sensation and Its Sensitivity to Tissue Thickness Vriation}

The purpose of this study was to investigate the effect of tissue differences on the local thermal sensation of the head. Numerical results have shown that the tissue thickness difference has a significant effect on the temperature distribution and also directly affect local thermal sensation. In order to study the relationship between changes in tissue thickness and thermal sensation, or more specifically, to investigate how the thickness change of muscle tissue, adipose tissue and skin tissue affects the thermal sensation of head in an uniformed environment, the thermal sensation index sensitivity analysis was performed, and the results are shown in Figure 10.

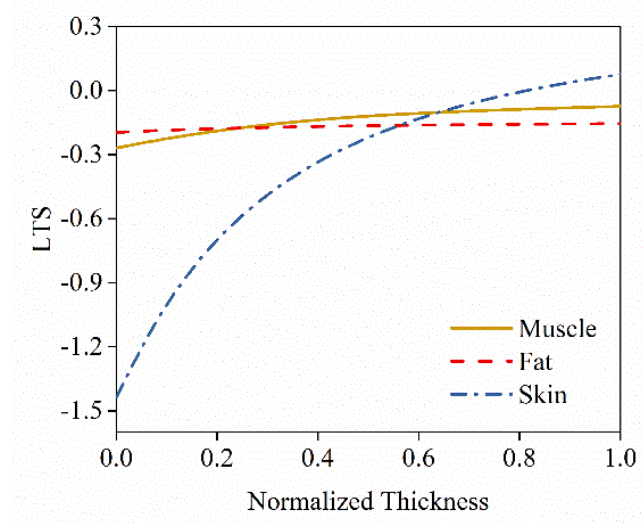

(a)

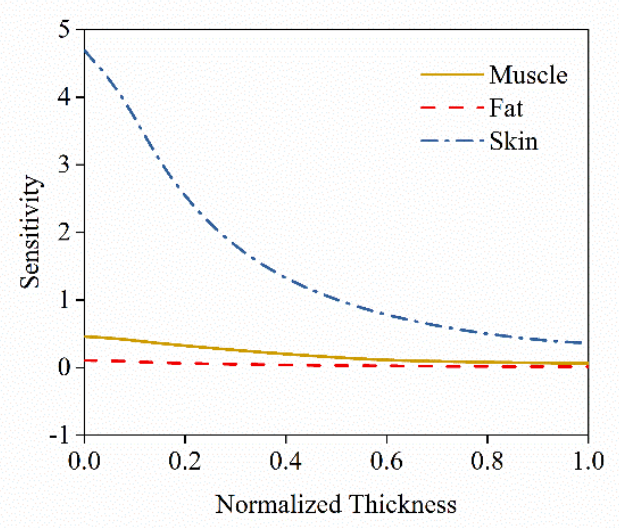

(b)

Figure 10. (a) The variation of the thermal sensation index with tissue thickness change; (b) the sensitivity of the thermal sensation index to tissue thickness change.

In Figure 10a, the curve shows the change of the thermal sensation of the head relative to the normalized thickness change of the three tissues (muscle, fat, and skin). During the gradual increase in the thickness of the three tissues (muscle, fat, and skin), it can be clearly seen that the thermal sensation index of the head is gradually increasing. The increase in skin thickness has the greatest effect on the thermal sensation of the head which result in the thermal sensation index increasing from a negative value to a positive value. It can be seen from the figure that when the value of skin thickness is the smallest, the head thermal sensation index LTS is about -1.44 , and when the skin thickness is the largest, the thermal sensation index LTS is about 0.076 , which has a wide range of variation. For muscle tissue and adipose tissue, there is a definite change in the thermal sensation index of the head, but the change is not as large as the effect of skin on heat sensation. However, from the numerical result when the muscle thickness is the largest, the LTS is about -0.074 , and when the fat thickness is the largest, the LTS is about -0.154 . This means that increased muscle and fat thickness has less effect on thermal sensation. 
Figure $10 \mathrm{~b}$ is the sensitivity of the head thermal sensation index to the standardized thickness of three tissues (muscle tissue, adipose tissue, and skin tissue). It can be seen that the sensitivity of the thermal sensation index to the change of skin thickness is the highest. That means the thermal sensation of the head is easily affected by skin thickness change. However, this affect is not changed in a linear form. In the initial stage, the increase in skin thickness has a significant effect on improving thermal sensation, but as the skin thickness continues to increase, the skin's effect on increasing thermal sensation becomes slower and the sensitivity of thermal sensation decreases gradually until, in the end, it gradually flattens out, which means that when the skin thickness is high, the thermal sensation of head is less sensitive to skin thickness change.

The sensitivity of thermal sensation to muscle tissue and adipose tissue is at a relatively low level, indicating that the increase in the thickness of these two tissues has a lower effect on changing the thermal sensation of the head. The reason for this phenomenon is that the thermal conductivity of adipose tissue itself is very low, and when the thickness or content is not high, it can play a better thermal insulation effect. As the thickness increases, it does not decrease the temperature of the skin further. For muscle tissue, it has a similar effect to fat tissue, as analyzed for temperature changes in a previous section. This leads to the sensitivity of the results in Figure 10b.

\section{Conclusions}

The purpose of this study was to investigate the influence of the head's internal structure and composition on head temperature distribution and local thermal sensation through numerical calculations. The following conclusions were reached:

(1) In this work, a mathematical model suitable for calculating head temperature was established, in which the active system was established based on the fuzzy control theory, and the usability of this model was proved by comparing it with public data.

(2) The physiological parameters of the head were obtained by MRI, and obvious differences were found in the physiological parameters between individuals, which would have certain influence on the simulation of human thermal comfort.

(3) Based on the mathematical model and the obtained physiological parameters, the temperature distribution under the conditions of different head structures and tissue thickness parameters was calculated. The results show that different internal structures cause differences in skin surface temperature, with the highest skin temperature being $34.17^{\circ} \mathrm{C}$ on the forehead, and the lowest $33.94{ }^{\circ} \mathrm{C}$, with a difference of $0.24^{\circ} \mathrm{C}$. The results of the regression analysis showed that skin thickness had the largest influence on head temperature, followed by muscle tissue, and the least influence was adipose tissue, with the influence coefficients of $C_{\text {muscle }}=0.0127, C_{\text {fat }}=0.0097$, and $C_{\text {skin }}=0.0180$, respectively.

(4) Local thermal sensation of the head is sensitive to changes in tissue thickness. Local thermal sensation was most sensitive to skin thickness differences, with the highest sensitivity coefficient of 4.69 , the lowest of 0.36 , and the average of 1.58 . The highest sensitivity to muscle tissue was 0.46 , the lowest 0.64 , and the average 0.2 , while the sensitivity coefficient of fat was relatively small, with the highest of 0.11 , the lowest of 0.013 , and the average of 0.04 .

Author Contributions: Conceptualization, Y.Z.; investigation, S.H.; methodology, S.H.; resources, Y.G.; visualization, G.Z.; writing-original draft, S.H.; writing-review and editing, Z.H. All authors have read and agreed to the published version of the manuscript.

Acknowledgments: The authors appreciate the financial support of project No. 51974015, No. 51904292 and No. 51474017 provided by the National Natural Science Foundation of China, project No. 2017CXNL02 provided by the Fundamental Research Funds for the Central Universities (China University of Mining and Technology), project No. BK20180655 provided by the Natural Science Foundation of Jiangsu Province of China, project No. WS2018B03 provided by the State Key Laboratory Cultivation Base for Gas Geology and Gas Control (Henan Polytechnic University), and project No. E21724 provided by the Work Safety Key Lab on Prevention and Control of Gas and Roof Disasters for the Southern Coal Mines of China (Hunan University of Science and Technology).

Conflicts of Interest: The authors declare no conflict of interest. 


\section{References}

1. Yang, Y.; Yao, R.; Li, B.; Liu, H.; Jiang, L. Parameterization of Temperature Perception of Ventilation Changes in Full-Face Motorcycle. Build. Environ. 2015, 87, 1-9. [CrossRef]

2. Johnson, A.T. Respirator masks protect health but impact performance: A review. J. Biol. Eng. 2016, 10, 4. [CrossRef] [PubMed]

3. Bogerd, C.P.; Aerts, J.M.; Annaheim, S.; Bröde, P.; de Bruyne, G.; Flouris, A.D.; Kuklane, K.; Sotto Mayor, T.; Rossi, R.M. A review on ergonomics of headgear: Thermal effects. Int. J. Ind. Ergon. 2015, 45, 1-12. [CrossRef]

4. Yang, Y.; Yao, R.; Li, B.; Liu, H.; Jiang, L. Modelling of the microclimate saturation inside a safety helmet. Build. Environ. 2015, 87, 1-9. [CrossRef]

5. Halimi, M.T.; Dhahri, H.; Khedher, N.B.; Hassen, M.B.; Sakli, F. Thermal Properties of Industrial Safety Helmets. Build. Environ. 2009, 5, 833-844.

6. Underwood, L.; Vircondelet, C.; Jermy, M. Thermal comfort and drag of a streamlined cycling helmet as a function of ventilation hole placement. Proc. Inst. Mech. Eng. Part P J. Sports Eng. Technol. 2018, 232, 15-21. [CrossRef]

7. Ghani, S.; ElBialy, E.M.A.A.; Bakochristou, F.; Gamaledin, S.M.A.; Rashwan, M.M. The effect of forced convection and PCM on helmets' thermal performance in hot and arid environments. Appl. Therm. Eng. 2017, 111, 624-637. [CrossRef]

8. Bogerd, C.P.; Walker, I.; Brühwiler, P.A.; Rossi, R.M. The effect of a helmet on cognitive performance is, at worst, marginal: A controlled laboratory study. Appl. Ergon. 2014, 45, 671-676. [CrossRef]

9. Kobayashi, Y.; Tanabe, S.I. Development of JOS-2 human thermoregulation model with detailed vascular system. Build. Environ. 2013, 66, 1-10. [CrossRef]

10. Lv, Y.G.; Liu, J. Effect of transient temperature on thermoreceptor response and thermal sensation. Build. Environ. 2007, 42, 656-664. [CrossRef]

11. Foda, E.; Almesri, I.; Awbi, H.B.; Sirén, K. Models of human thermoregulation and the prediction of local and overall thermal sensations. Build. Environ. 2011, 46, 2023-2032. [CrossRef]

12. Zhou, X.; Xiong, J.; Lian, Z. Predication of skin temperature and thermal comfort under two-way transient environments. J. Therm. Biol. 2017, 70, 15-20. [CrossRef] [PubMed]

13. Lan, L.; Tsuzuki, K.; Liu, Y.F.; Lian, Z.W. Thermal environment and sleep quality: A review. Energy Build. 2017, 149, 101-113. [CrossRef]

14. Salloum, M.; Ghaddar, N.; Ghali, K. A new transient bioheat model of the human body and its integration to clothing models. Int. J. Therm. Sci. 2007, 46, 371-384. [CrossRef]

15. Irzmańska, E. Case study of the impact of toecap type on the microclimate in protective footwear. Int. J. Ind. Ergon. 2014, 44, 706-714. [CrossRef]

16. Zolfaghari, A.; Maerefat, M. A new simplified thermoregulatory bioheat model for evaluating thermal response of the human body to transient environments. Build. Environ. 2010, 45, 2068-2076. [CrossRef]

17. Ludwig, N.; Trecroci, A.; Caumo, A.; Alberti, G.; Michielon, G.; Formenti, D.; Gargano, M. Dynamics of thermographic skin temperature response during squat exercise at two different speeds. J. Therm. Biol. 2016, $59,58-63$.

18. Neves, E.B.; Salamunes, A.C.C.; de Oliveira, R.M.; Stadnik, A.M.W. Effect of body fat and gender on body temperature distribution. J. Therm. Biol. 2017, 70, 1-8. [CrossRef]

19. Lakhssassi, A.; Kengne, E.; Semmaoui, H. Modifed pennes' equation modelling bio-heat transfer in living tissues: Analytical and numerical analysis. Nat. Sci. 2010, 2, 1375-1385. [CrossRef]

20. Dixit, A.; Gade, U. A case study on human bio-heat transfer and thermal comfort within CFD. Build. Environ. 2015, 94, 122-130. [CrossRef]

21. Tuzikiewicz, W.; Duda, M. Bioheat transfer equation. The problem of FDM explicit scheme stability. J. Appl. Math. Comput. Mech. 2015, 14, 139-144. [CrossRef]

22. Lakhssassi, A.; Kengne, E.; Semmaoui, H. Investigation of nonlinear temperature distribution in biological tissues by using bioheat transfer equation of Pennes' type. Nat. Sci. 2010, 2, 131-138. [CrossRef]

23. Yang, J.-H.; Kato, S.; Seo, J. Evaluation of the Convective Heat Transfer Coefficient of the Human Body Using the Wind Tunnel and Thermal Manikin. J. Asian Archit. Build. Eng. 2009, 8, 563-569. [CrossRef] 
24. Cano, S.P.; Sillero-Quintana, M.; Brito, C.J.; de Andrade Fernandes, A.; Bouzas Marins, J.C.; Costa, C.M.A.; de Azambuja Pussieldi, G.; Moreira, D.G. Daily rhythm of skin temperature of women evaluated by infrared thermal imaging. J. Therm. Biol. 2017, 72, 1-9.

25. Kaynakli, O.; Kilic, M. Investigation of indoor thermal comfort under transient conditions. Build. Environ. 2005, 40, 165-174. [CrossRef]

26. Pang, T.Y.; Subic, A.; Takla, M. Thermal comfort of cricket helmets: An experimental study of heat distribution. Procedia Eng. 2011, 13, 252-257. [CrossRef]

27. Bogerd, C.P.; Rossi, R.M.; Brühwiler, P.A. Thermal perception of ventilation changes in full-face motorcycle helmets: Subject and manikin study. Ann. Occup. Hyg. 2011, 55, 192-201.

28. Mehnert, P.; Malchaire, J.; Kampmann, B.; Piette, A.; Griefahn, B.; Gebhardt, H. Prediction of the average skin temperature in warm and hot environments. Eur. J. Appl. Physiol. 2000, 82, 52-60. [CrossRef]

29. Zhou, X.; Lian, Z.; Lan, L. An individualized human thermoregulation model for Chinese adults. Build. Environ. 2013, 70, 257-265. [CrossRef]

30. Kubota, H.; Kuwabara, K.; Hamada, Y. Prediction of mean skin temperature for use as a heat strain scale by introducing an equation for sweating efficiency. Int. J. Biometeorol. 2014, 58, 1593-1603. [CrossRef]

31. Mairiaux, P.; Malchaire, J.; Candas, V. Prediction of mean skin temperature in warm environments. Eur. J. Appl. Physiol. Occup. Physiol. 1987, 56, 686-692. [CrossRef] [PubMed]

32. Katić, K.; Li, R.; Kingma, B.; Zeiler, W. Modelling hand skin temperature in relation to body composition. J. Therm. Biol. 2017, 69, 139-148. [CrossRef]

33. Abu Bakar, R.; Jusoh, N.; Rasdan Ismail, A.; Zanariah Shamshir Ali, T. Effect on human metabolic rate of skin temperature in an office occupant. MATEC Web Conf. 2017, 90, 01070. [CrossRef]

34. Laird, I.S.; Goldsmith, R.; Pack, R.J.; Vitalis, A. The effect on heart rate and facial skin temperature of wearing respiratory protection at work. Ann. Occup. Hyg. 2002, 46, 143-148. [PubMed]

35. Fiala, D.; Lomas, K.J.; Stohrer, M. A computer model of human thermoregulation for a wide range of environmental conditions: The passive system. J. Appl. Physiol. 2017, 87, 1957-1972. [CrossRef] [PubMed]

36. Dongmei, P.; Mingyin, C.; Shiming, D.; Minglu, Q. A four-node thermoregulation model for predicting the thermal physiological responses of a sleeping person. Build. Environ. 2012, 52, 88-97. [CrossRef]

37. Katić, K.; Li, R.; Zeiler, W. Thermophysiological models and their applications: A review. Build. Environ. 2016, 106, 286-300. [CrossRef]

38. Havenith, G.; Fiala, D. Thermal indices and thermophysiological modeling for heat stress. Compr. Physiol. 2016, 6, 255-302.

39. Zhu He, Z.; Xue, X.; Liu, J. An Effective Finite Difference Method for Simulation of Bioheat Transfer in Irregular Tissues. J. Heat Transf. 2013, 135, 071003. [CrossRef]

40. Lai, D.; Zhou, X.; Chen, Q. Modelling dynamic thermal sensation of human subjects in outdoor environments. Energy Build. 2017, 149, 16-25. [CrossRef]

41. Lai, D.; Chen, Q. A two-dimensional model for calculating heat transfer in the human body in a transient and non-uniform thermal environment. Energy Build. 2016, 118, 114-122. [CrossRef]

42. Weigert, M.; Nitzsche, N.; Kunert, F.; Lösch, C.; Schulz, H. The influence of body composition on exercise-associated skin temperature changes after resistance training. J. Therm. Biol. 2018, 75, 112-119. [CrossRef] [PubMed]

43. Salamunes, A.C.C.; Stadnik, A.M.W.; Neves, E.B. The effect of body fat percentage and body fat distribution on skin surface temperature with infrared thermography. J. Therm. Biol. 2017, 66, 1-9. [CrossRef] [PubMed]

44. Davoodi, F.; Hassanzadeh, H.; Zolfaghari, S.A.; Havenith, G.; Maerefat, M. A new individualized thermoregulatory bio-heat model for evaluating the effects of personal characteristics on human body thermal response. Build. Environ. 2018, 136, 62-76. [CrossRef]

45. Ziade, G.; Semaan, S.; Ghulmiyyah, J.; Kasti, M.; Hamdan, A.L.H. Structural and Anatomic Laryngeal Measurements in Geriatric Population Using MRI. J. Voice 2017, 31, 359-362. [CrossRef]

46. Chia, C.W.; Ferrucci, L.; Spencer, R.G.; Fishbein, K.W.; Makrogiannis, S.K.; Lukas, V.A.; Okine, M.; Egan, J.M.; Ramachandran, R. Measurement of fat fraction in the human thymus by localized NMR and three-point Dixon MRI techniques. Magn. Reson. Imaging 2018, 50, 110-118.

47. Lack, C.M.; Lesser, G.J.; Umesi, U.N.; Bowns, J.; Chen, M.Y.; Case, D.; Hightower, R.C.; Johnson, A.J. Making the most of the imaging we have: Using head MRI to estimate body composition. Clin. Radiol. 2016, 71, e1-e402. [CrossRef] 
48. Brooks, T.; Choi, J.E.; Garnich, M.; Hammer, N.; Waddell, J.N.; Duncan, W.; Jermy, M. Finite element models and material data for analysis of infant head impacts. Heliyon 2018, 4, e01010. [CrossRef] [PubMed]

49. Zhang, H.; Arens, E.; Huizenga, C.; Han, T. Thermal sensation and comfort models for non-uniform and transient environments: Part I: Local sensation of individual body parts. Build. Environ. 2010, 45, 380-388. [CrossRef]

50. Zhang, H.; Arens, E.; Huizenga, C.; Han, T. Thermal sensation and comfort models for non-uniform and transient environments, part II: Local comfort of individual body parts. Build. Environ. 2010, 45, 389-398. [CrossRef]

51. Tanabe, S.I.; Kobayashi, K.; Nakano, J.; Ozeki, Y.; Konishi, M. Evaluation of thermal comfort using combined multi-node thermoregulation (65 MN) and radiation models and computational fluid dynamics (CFD). Energy Build. 2002, 34, 637-646. [CrossRef]

(C) 2020 by the authors. Licensee MDPI, Basel, Switzerland. This article is an open access article distributed under the terms and conditions of the Creative Commons Attribution (CC BY) license (http://creativecommons.org/licenses/by/4.0/). 